J. Clin. Chem. Clin. Biochem.

Vol. 19, 1981, pp. 1197-1200

\title{
Evaluation and Modification of a Radioimmunoassay for Pregnancy-specific $\beta_{1}$-Glycoprotein
}

\author{
By $H . A$. Bonte and G. van der Sluijs Veer \\ Streekziekenhuis Midden-Twente, Department of Clinical Chemistry, Hengelo (O), The Netherlands
}

(Received December 11, 1980/July 14, 1981)

Summary: The radioimmunoassay available from Behringwerke for pregnancy-specific $\beta_{1}$-glycoprotein $\left(\mathrm{SP}_{1}\right)$ was tested for its ability to detect pregnancy prior to the first missed menstrual period.

It was found that the equine serum, used as solvent for the standards, did not react like human serum.

The standard solvent was replaced by bovine serum albumin $50 \mathrm{~g} / \mathrm{l}$ and pooled human serum respectively. Equilibrium and sequential incubation procedures were compared. The latter appeared to be more sensitive in the low value range and was therefore more suitable for the early detection of pregnancy.

Also, with standards in albumin, the sequential assay was more specific.

$\mathrm{SP}_{1}$ could be detected in sera of men and non-pregnant women, using albumin as standard solvent.

This could be due to different cross reacting material of the protein matrix, or to the presence of $\mathrm{SP}_{1}$-like material in human sera.

The choice of human male serum seemed to be the most practical. It has also been adopted by Behring, and a commercial kit has been prepared.

Prüfung, Bewertung und Modifikation eines Radioimmunassay für schwangerschaftsspezifisches $\beta_{1}$-Glykoprotein

Zusammenfassung: Der bei den Behringwerken erhältliche Radioimmunassay für schwangerschaftsspezifisches $\beta_{1}$-Glykoprotein wurde auf seine Eignung, eine Schwangerschaft bereits vor der ersten ausgebliebenen Menstrualblutung nachzuweisen, geprüft.

Wir fanden, daß das als Matrix für die Standards benutzte Pferdeserum nicht wie Humanserum reagiert.

Die Matrix für die Standards wurde ersetzt durch $50 \mathrm{~g} / 1$ Rinderserumalbumin bzw. Poolserum. Ein GleichgewichtsVerfahren und ein Verfahren mit sequentieller Inkubation wurden verglichen. Das sequentielle Verfahren schien in niedrigen Konzentrationsbereichen empfindlicher zu sein und war deshalb geeigneter für den frühen Nachweis einer Schwangerschaft. Auch mit Standards in Albumin war das sequentielle Verfahren spezifischer.

Schwangerschạtstspezifisches $\beta_{1}$-Glykoprotein konnte im Serum von Männern und nicht-schwangeren Frauen mit Albumin als Matrix für die Standards nachgewiesen werden. Dies könnte durch unterschiedliches kreuzreagierendes Material der Proteinmatrix oder durch das Vorkommen von schwangerschaftsspezifischem $\beta_{1}$-Glykoprotein-ähnlichem Material in menschlichen Seren bedingt sein.

Dịe Wahl von Männerseren als Matrix für die Standards schien am praktischsten zu sein. Dies wurde auch von den Behringwerken übernommen und ein käuflicher Test entwickelt.

\section{Introduction}

There is a rapidly growing interest in placental proteins (1). One of the most recently discovered is the so called pregnancy-specific $\beta_{1}$-glycoprotein (SP. 1 or $P S \beta G$ ), also called trophoblast-specific $\dot{\beta}_{1}$-globulin, or pregnancy associated plasma protein $\mathrm{C} . \mathrm{SP}_{1}$ is a glycoprotein, containing about $28 \%$ carbohydrate. It has a molecular weight of 90,000 daltons. Immunological heterogeneity has been described (2). It is produced by the syncytiotrophoblast of the placenta and secreted in the maternal 
(intervillous) circulation. $\mathrm{SP}_{1}$ levels increase rapidly during gestation (3). it has been shown to have immunosuppressive activity. It may therefore play a part in preventing the rejection of the developing blastocyst (4).

Trophoblastic tumours and some other neoplasms can produce $\mathrm{SP}_{1}$ (5). The evidence concerning the presence of $\mathrm{SP}_{1}$ in the serum of healthy men and non-pregnant women is conflicting (6-9).

In a study concerning the incidence of occult abortion a very sensitive indicator of pregnancy was needed. Measurements of human chorionic gonadotropin were not taken into consideration because some of the patients had been treated with this hormone to induce ovulation. The aim of this present study was to test the suitability of the Behring $\mathrm{SP}_{1}$ reagents.
The physiological function of $\mathrm{SP}_{1}$ is not yet known, but

\section{Results}

\section{Assay characteristics}

The $\mathrm{SP}_{1}$ radioimmunoassay was performed by standard procedures and also by a sequential incubation technique. Binding characteristics for both assays are listed in table 1. Typical standard curves are given in figures 1 and 2 .

Tab. 1. Comparison of several characteristics of the two procedures for $\mathrm{SP}_{1}$ estimation. Mean \pm S.D. of 7 series of estimations are given.

\begin{tabular}{lcc}
\hline & $\begin{array}{l}\text { Standard } \\
\text { procedure }\end{array}$ & $\begin{array}{l}\text { Sequential } \\
\text { incubation }\end{array}$ \\
\hline $\begin{array}{l}\text { Mean binding capacity } \\
\text { (Bo as fraction of total } \\
\text { counts) }\end{array}$ & $0.43 \pm 0.04$ & $0.45 \pm 0.05$ \\
$\begin{array}{l}\text { Mean } S P_{1} \text { level at } \mathrm{B} / \mathrm{B}_{0} \\
\text { of } 0.90(\mu \mathrm{g} / \mathrm{l} \pm \mathrm{SD})\end{array}$ & $4.8 \pm 1.3$ & $1.3 \pm 0.4$ \\
$\begin{array}{l}\text { Mean } \mathrm{SP} \\
\text { of level at } \mathrm{B} / \mathrm{B}_{0}\end{array}$ & $44.50(\mu \mathrm{g} / 1 \pm \mathrm{SD})$ \\
$\begin{array}{l}\text { Dynamic range }(\mu \mathrm{g} / \mathrm{l}) \text { up to } \\
\text { Dyn }\end{array}$ & 250 & $10.5 \pm 1.0$ \\
\hline
\end{tabular}

\section{Materials and Methods}

Blood was collected from healthy men and non-pregnant women, and from pregnant women some of which had conceived after ovulation induction. Venous blood was drawn, allowed to clot at room temperature and centrifuged for $10 \mathrm{~min}$ at $1,600 \mathrm{~g}$. The serum was decanted and stored in fractions at $-18^{\circ} \mathrm{C}$.

\section{Radioimmunoassay of $\mathrm{SP}_{1}$}

Serum levels of $\mathrm{SP}_{1}$ were measured in a double-antibody radioimmunoassay. Reagents were supplied by Behringwerke . (Marburg/Lahn, GFR).

${ }^{125}$ I labeled-SP $P_{1}$, specific activity about $1.48 \times 10^{12} \mathrm{~Bq} / \mathrm{g}$ $(40 \mathrm{mCi} / \mathrm{mg})$, was used without further purification. $\mathrm{SP}_{1}$ standards ( ${ }^{\circ}$ OTIL 02/03) were dissolved in equine serum in the range $0-360 \mu \mathrm{g} / \mathrm{l}$. Standards or sera were diluted with $0.1 \mathrm{~mol} / 1$ phosphate buffer ( $\mathrm{pH} 7.4$ ), containing $0.05 \mathrm{~mol} / 1$ ethylenediaminetetraacetic acid (EDTA) and bovine serum albumin $(50 \mathrm{~g} / 1)$. Equine serum $A$ was obtained from the Rijksinstituut voor de Volksgezondheid, Bilthoven, the Netherlands, and bovine serum albumin (fraction V, A 8022) from Sigma (USA).

The assay conditions were as follows: tracer about $1.85 \times 10^{6} \mathrm{~Bq}$ $(50 \mathrm{nCi})$ in $200 \mu \mathrm{l}$ was added to $100 \mu \mathrm{l}$ of serum in polystyrene tubes, $200 \mu \mathrm{l}$ anti-SP $\mathrm{P}_{1}$ antiserum was then added and incubated at room temperature for $16-24 \mathrm{~h}$.

Radioactivity bound to the antibody was precipitated with $100 \mu$ l of sheep antirabbit $\gamma$-globulin serum using an incubation time of $1.5-4 \mathrm{~h}$, followed by centrifugation for $15 \mathrm{~min}$ at $1,400 \mathrm{~g}$. The supernatant was decanted and aspirated off and the precipitates were counted for $2 \mathrm{~min}$ in a PW 4580 Automatic Gamma Analyser (Philips, Eindhoven, The Netherlands). We call this the "equilibrium" procedure.

All counts were corrected by subtracting blank values from incubations where the anti-SP $\mathbf{1}_{1}$-antiserum was replaced by buffer.

In a modified, sequential assay technique, the incubation was started with anti-SP ${ }_{1}$-antiserum and serum samples. After 16-24 $\mathrm{h}$ the tracer was added and a second incubation of 16-24 h followed. Precipitation was performed as described above.

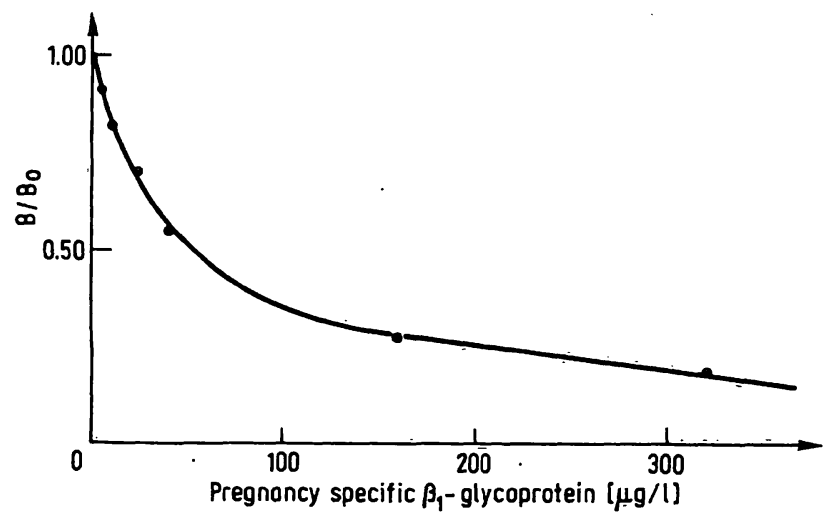

Fig. 1. Standard curve obtained, following the manufacturer's instructions.

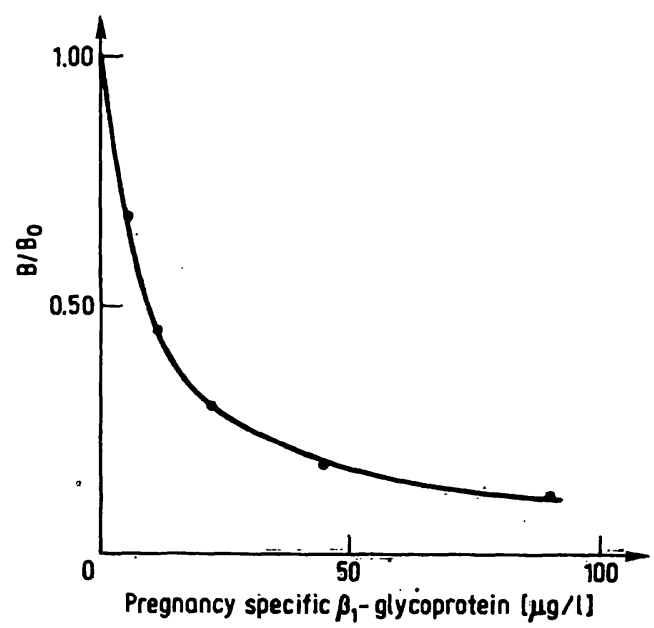

Fig. 2. Standard curve obtained, according to the,sequential incubation procedure. 
In the "equilibrium" incubation procedure the logitlog calibration curves were linear with a slope of $-1.03 \pm 0.13$ (S.D.). Blank values were low, never exceeding a fraction of 0.02 of $B_{0}$. Binding capacity for $\mathrm{SP}_{1}$ was further evaluated in Scatchard plots. Since the binding was not complete after $24 \mathrm{~h}$, a five days incubation at room temperature was carried out. Scatchard plots were not linear, indicating heterogeneity of the antibody (fig. 3).

Following the method described by Schöneshöfer (10) and assuming two binding components, association constants $(\mathrm{K})$ and antibody concentrations (Ab) were calculated

$$
\begin{array}{ll}
\mathrm{K}_{1}=81 \times 10^{-2} \mathrm{~K}_{2}=7 \times 10^{-2} 1 / \mu \mathrm{SP}_{1} \\
\mathrm{Ab}_{1}=1.6 \quad \mathrm{Ab}_{2}=2.0 \quad \mu \mathrm{g} / 1 \mathrm{SP}_{1} .
\end{array}
$$

The sequential procedure gave a more sensitive assay. Performance of both procedures at $4{ }^{\circ} \mathrm{C}$ produced no improvement in the results.

The intra-assay reproducibility of both assay procedures is shown in table 2. The more sensitive procedure of sequential incubation leads to a better reproducibility for low $\mathrm{SP}_{1}$ levels.

\section{Effects of different standard solvents}

Using the standard procedure, sera of healthy men and non-pregnant women were analysed. Almost all $\mathrm{B} / \mathrm{B}_{0}$

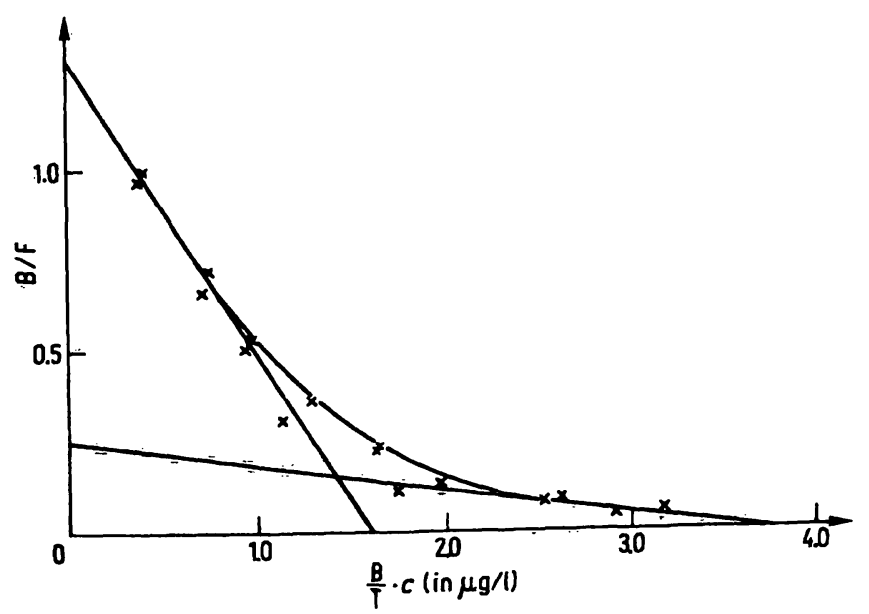

Fig. 3. Scatchard plot showing heterogeneity of the antibody.

\begin{tabular}{|c|c|c|c|c|c|c|}
\hline & $\begin{array}{l}\text { Standard proce } \\
(\mu \mathrm{g} / \mathrm{l} \pm \text { S.D.) }\end{array}$ & $\begin{array}{l}\text { dure } \\
\text { CV } \\
(\%)\end{array}$ & $\mathbf{n}$ & $\begin{array}{l}\text { Sequential inc } \\
(\mu \mathrm{g} / 1 \pm \text { S.D.) }\end{array}$ & $\begin{array}{l}\text { ubatior } \\
\text { CV } \\
\text { (\%) }\end{array}$ & $\begin{array}{r}\text { on } \\
\mathbf{n}\end{array}$ \\
\hline $\begin{array}{l}\text { Low } \mathrm{SP}_{1} \\
\text { level }\end{array}$ & $7.4 \pm 1: 0$ & 13.5 & 20 & $8.1 \pm 0.4$ & 4.9 & 15 \\
\hline $\begin{array}{l}\text { Medium } \mathbf{S P}_{\mathbf{1}} \\
\text { level }\end{array}$ & $75.8 \pm 3.1$ & 4.1 & 19 & $13.4 \pm 1.1$ & 8.2 & 15 \\
\hline $\begin{array}{l}\text { High } S_{1} \\
\text { level }\end{array}$ & $109.3 \pm 5.4$ & 4.9 & 18 & $36.4 \pm 3.0$ & 8.2 & 14 \\
\hline
\end{tabular}

Tab. 2. Comparison of intra-assay reproducibility in two pro- values were greater than 1.00 , leading to "negative" $\mathrm{SP}_{1}$ values. This could be explained by assuming that the standards dissolved in equine serum contained a material reacting like $\mathrm{SP}_{1}$ in this assay. This was further elucidated by testing standards in different media.

Standards were prepared in the concentration range $5.6-360 \mu \mathrm{g} / 1$, in the following media:

Bovine serum albumin $50 \mathrm{~g} / \mathrm{l}$ in water, pooled human male serum and in equine serum. Dilutions of sera were made up in the same media.

The dose response curves parallel those of the original curves (fig. 4).

The bovine serum albumin solvent gave the highest fraction of zero binding. Values of about $10 \mu \mathrm{g} / 1$ were found for the equine serum and from $5-10 \mu \mathrm{g} / 1$ for the male serum, when read on a standard curve in bovine serum albumin.

Using the sequential incubation technique, the differences were up to $5 \mu \mathrm{g} / \mathrm{l}$.

On the basis of these findings it seemed justified to abandon the equine serum, and to replace it with albumin and human male serum as a standard solvent.

\section{Levels of $S P_{1}$ in non-pregnant subjects}

The sera of 22 men and non-pregnant women were analysed, by equilibrium and sequential incubation procedures. The minimal detectable dose (MDD), defined as the dose at a distance of two standard deviations from the mean $B_{0}(n=20)$ was estimated.

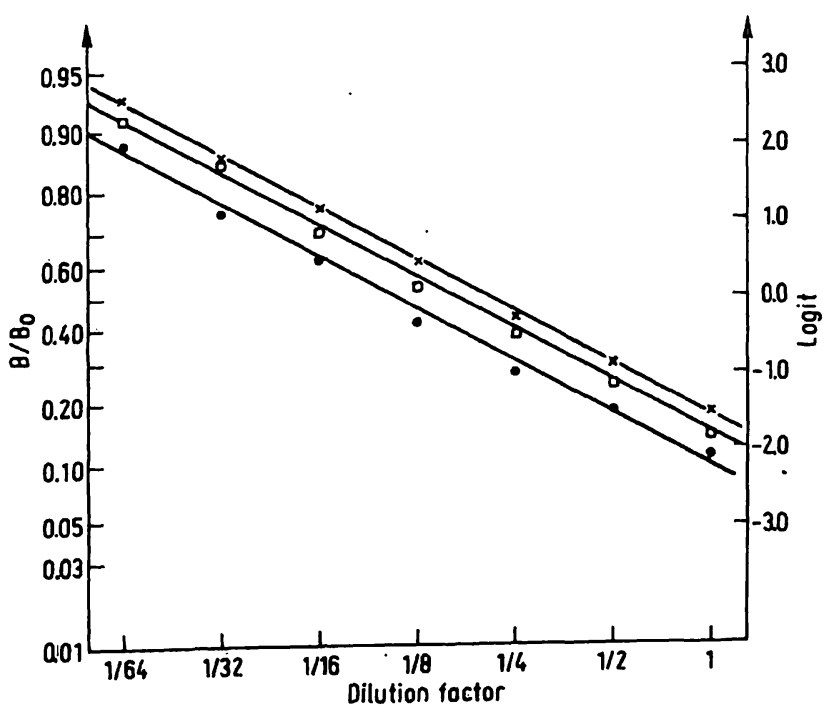

Fig. 4. Logit-log plot showing an example of the parallelism tested $x-x$ : Equine serum $A$, diluted with human male serum. - $a$ : Equine serum $A$, diluted with bovine serum albumin.

- - $\because$ Standard series, diluted with equine serum. The undiluted standard was $360 \mu \mathrm{g} / \mathrm{l}$. 
The results are presented in table 3.

The non-pregnant values found, using the standards in albumin and following the equilibrium procedure, seemed rather high, when compared with values in the literature (6-9).

Estimation of $\mathrm{SP}_{1}$ in the same subjects by the sequential incubation procedure, resulted in lower values. Possibly the sequential incubation procedure also leads to a more specific $\mathrm{SP}_{1}$ estimation, although the values found still differ significantly from zero.

The same effect was not noticed using standards in human male serum.

Tab. 3. Non-pregnant values and minimal detectable dose (MDD) following four different procedures for $\mathrm{SP}_{1}$-radioimmunoassay.

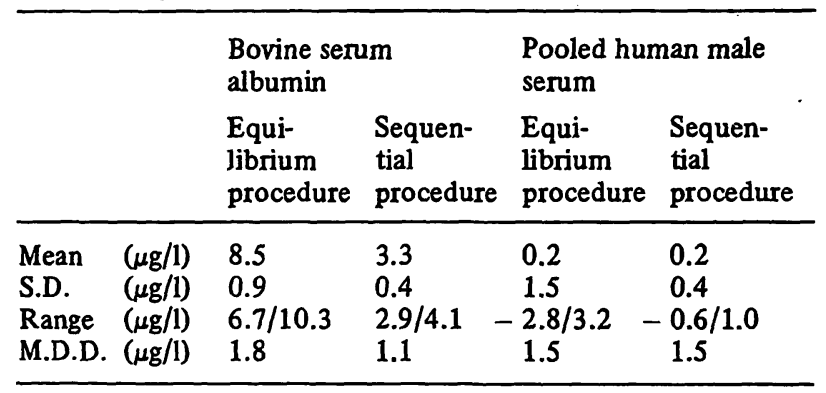

\section{Discussion}

Detection of a pregnancy-specific substance in the earliest possible phase of pregnancy requires a very sensitive and specific assay. In its original form the Behring-kit was not suitable for this purpose, so we tried to modify the procedure. Systematic differences in the assay of up to $10 \mu \mathrm{g} / 1$ indicated the importance of the standard medium. The original standards in equine serum were therefore replaced by standards in albumin and in pooled human male serum.
With the former method a $\mathrm{SP}_{1}$-like substance was found in sera of men and non-pregnant women. Further studies are required to reveal the nature and origin of this "SP.".

Of course matrix effects could play a role, although one cannot exclude the presence of cross reacting material. It is also possible that the heterogeneity, detected in the antibody, plays a role or that purification of the tracer may lead to a reduction of the cross reaction.

Our experience with the different standard diluents perhaps gives an indication why some authors do find a detectable amount of $\mathrm{SP}_{1}$ in non-pregnant sera, while others do not. In our opinion the "positive" value of $1.7 \mu \mathrm{g} / 1$ found by Seppälä (11) ten days after AID (Artificial Insemination Donor) could fall within the non-pregnant range. In an ongoing study with sera of pregnant women there is evidence that $\mathrm{SP}_{1}$ increments above the upper limit of non-pregnant values are seen 14-17 days after ovulation. Thereafter the levels increase exponentially to values of $300-400 \mu \mathrm{g} / 1$ within one week (data to be published).

The sequential procedure is so sensitive that it seems useful only for a few days after the detection of $\mathrm{SP}_{1}$ levels above the non-pregnant values.

Using the equilibrium procedure, with standards in pooled human male serum, values above $3 \mu \mathrm{g} / 1$ indicate pregnancy, whereas the corresponding value for the modified sequential procedure is $1 \mu \mathrm{g} / 1$. Because of the minimal detectable dose in the latter case the cut-off value lies at $1.5 \mu \mathrm{g} / 1$. Perhaps it is possible to detect pregnancy very early in a longitudinal series of $\mathrm{SP}_{1}$-determinations, by detecting an increase in $\mathrm{SP}_{1}$. In that case the assay must be optimal in the low $\mathrm{SP}_{1}$-region. A sequential assay seems to fulfill this requirement best.

\section{Acknowledgements}

We thank Dr. W. Wacheck from Behringwerke, who supplied the $\mathrm{SP}_{1}$-reagents and gave financial support, and Prof. $H$. J. Huisfes and Dr. H. W. A. de Bruyn for their help in the preparation of the manuscript.

\section{References}

1. Klopper, A. \& Chard, T. (eds.) (1975) Placental Proteins, Springer Verlag, Berlin, Heidelberg, New York.

2. Towler, C. M., Clover, Robyn G. \& Horne, C. H. W. (1978) Clin. Chim. Acta 87, 289-296.

3. Towler, C. M., Jandial, V., Horne, C. H. W. \& Bohn, H. (1976) Br. J. Obstet. Gyn. 83, 368-374. . .

4. Cerni, C., Tatra, G. \& Bohn, H. (1977) Arch. Gynäk. 223, $1-7$.

5. Tatarinov, Y. S. \& Sokolov, A. V. (1977) Int. J. Cancer 19, 161-165.

6. Kaminska, J., Calvert, I. \& Rosen, S. W. (1979) Clin. Chem. $25,577-580$.

7. Towler, C. M., Horne, C. H. W., Jandial, V. \& Chesworth J. M. (1977) Br. J. Obstet. Gyn. 84, 580-584.

8. Grudz̃inskas, J. G., Gordon, Y. B., Jeffrey, D. \& Chărd, T. (1977) Lancet $I, 333-335$.

9. Grenner, G. (1978) Fresenius Z. Anal. Chem. 290, 99.

10. Schöneshöfer, M. (1977) Clin. Chim. Acta 77, 101-115.

11. Seppälä, M., Rönn berg, L., Ylöstalo, P. \& Jouppilla, P. (1979) Fertil. Steril. 32, 608-609. 